\title{
2002 Sarbanes-Oxley Act: Privately-Held Companies Implementation Issues
}

Ronald O. Reed, (E-mail: ronald.reed@unco.edu), University of Northern Colorado Thomas Buchman, University of Colorado, Boulder Richard Wobbekind, University of Colorado, Boulder

\begin{abstract}
Our research was designed to for two purposes: (1) if the provisions of SOX have merit on their own or whether it is just a mandate by legislators, and (2) to determine if privately-held companies currently not required to implement SOX have done so. In summary, the respondents, who were experienced financial executives with knowledge of SOX and other regulatory governance policies see SOX as an influential piece of legislation. They see some positive benefits to their organizations with implementation of some of the provisions of the act, such as better financing options, better credit opportunities, and opportunities to take the company public. Many of financial executives indicated their organizations are implementing provisions in areas where it cost effective as well making "good" business sense. For example, it is cost effective to implement a formal code of professional conduct for the executives and it does make good business sense. However they are not asking their CEOs or CFOs to certify the accuracy of financial statements nor to the internal control structure. Many of the financial managers indicated they are not implementing SOX on a full scale basis because of the cost, time, and that the lack of benefits derived from implementation.
\end{abstract}

\section{INTRODUCTION}

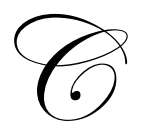

orporate governance, Wall Street and auditing reform regarding public companies have been in the forefront of Congressional and SEC activity during the past several years. Many know, Congress passed, and President Bush signed, the Sarbanes-Oxley Act (SOX) of 2002 providing unprecedented new requirements for auditors of public companies, publicly-held companies, and Wall Street. The cost has been significant to American businesses.

At the state level, several state legislators, regulators and other elected or appointed officials are seeking to duplicate and or extend provisions of the SOX to privately-held companies and their auditors. While some measures may have merit and could possibly be supported, some of what is being discussed is overreaching and simply should not apply to privately-held companies. As states consider some of these provisions, the potential for an adverse impact on privately-held businesses and the CPA firms which serve them is concerning. Privately-held businesses make up roughly half of the U.S. economy and are a primary source of economic growth and job creations. In an increasingly complex business world, these privately-held businesses depend upon profitability, and not added costs so they can continue to fuel that growth.

The costs that publicly-held companies have incurred because of Section 404 of SOX have been significant. A recent survey completed by the Financial Executives International (FEI) found that companies averaged $\$ 4.36$ million, up 39 percent from the $\$ 3.14$ million they expected to pay, as identified in FEI's July 2004 Section 404 survey. The increase stems largely from a 66 percent leap in external costs for consulting, software and other vendors and a 58 percent increase in the fees charged by external auditors (FEI, 2005). Furthermore, a study conducted by Broadgate Consultants, LLC concluded that an overwhelming majority (83\%) of the 105 institutional analysts and portfolio managers from across the U.S. responding to the survey, which covered a range of capital markets issues, 
say that the new rules relating to auditor testing and certification of companies' internal financial controls, required under section 404 of the Sarbanes-Oxley Act of 2002, should be modified to make compliance more cost-effective (Broadgate, 2005).

The costs associated with implementing some of the provisions of SOX, such as section 404 on internal controls, are quite costly to publicly-held companies and surely would be as costly to privately-held companies. However, there are certain sections and provisions of the act that would improve company governance and at a much lower cost to the companies. The benefits of complying with some of the provisions that are less costly could provide benefits that outweigh the costs.

There are numerous questions that relate to how SOX could impact privately-held companies. Obviously, if a privately-held company is considering going public in the near future or being a target for acquisition by a publiclyheld company, SOX has significantly more importance than companies that intend on remaining private. These types of privately-held companies should be considering a timeframe for organizing and developing a strategy to implementing SOX mandates. However, privately-held companies not considering going public or that are not targets by publicly-held companies maybe considering certain SOX sections because of a variety of reasons. Many legal professionals may encourage some compliance with SOX because they think that the legal system may view SOX as a benchmark for all business practices when there is a lack of guidance and regulation. Is it possible that courts and litigators would imply that the standard set for publicly-held companies is just as appropriate for privately-held companies when there is a lack of guidance and uniformity from regulators or the private markets? Other professionals argue that implementation of certain SOX provisions that improve reliability in financial reporting, such as designing and implementing improved internal control structures, can provide economic benefits in a lower cost of capital, lower insurance rates, and provide a more favorable impression of the company to its owners and other users of the financial statements. Other business professionals may argue that improved company governance and oversight is good business practices and it is not dependent upon the legal form of the business entity.

There have been two arguments for SOX: (1) increased investor confidence in financial statements issued by publicly held corporations and (2) to benefit adopting companies resulting from increased efficiency or reduced possibility of fraud or other reasons.

One would expect that if the provisions of SOX have merit on their own (other than being mandated), then companies not required to adopt those provision, would do so. On the other hand, if the company did not receive benefits from SOX's provisions - only investor confidence was increased, those private companies would not adopt them.

This research has two purposes: (1) to attempt to determine which argument above has the most validity and (2) to determine if privately-held companies currently not required to implement SOX have done so. Specifically, the following research questions or statements were asked of the respondents in a survey, which is discussed in the results section:

- Whether they believe that SOX is the benchmark for publicly-held company governance.

- Whether they believe that SOX is the benchmark for company governance.

- Whether they believe that privately-held companies that voluntarily adopt some of the provisions of SOX can better position themselves for:

o establishing stronger business credit.

o major financing options.

o enhancing credibility with key stakeholders.

o enhancing relationships with key stakeholders.

o a lower cost of capital from borrowing.

o a lower cost of insurance.

o taking the company public in the future. 
- $\quad$ Are there other benefits that could be derived from implementing some of the provisions of SOX?

- Is your company establishing:

o an internal audit function?

o an independent audit committee?

o a code of professional conduct for the CEO and other financial management?

o limiting or restricting services provided by your external auditing firm to avoid potential conflicts of interest?

o a more thorough management discussion and analysis section in the financial statements or annual report?

o a policy on whistleblower situations?

o a policy on setting the appointment for the external auditor?

o a policy on loans to officers?

o formal certifications of the financial statements?

o formal certifications of the internal control systems?

o guidelines to establish a financial expert on the audit committee or Board of Directors?

- Are there other provisions of SOX that your company has implemented or are considering for implementation?

- Does your company feel pressure to implement some of the provisions of SOX?

- If your company has decided not to implement some of the provisions of SOX, your reasons not to do so are because SOX is:

o Too costly?

o Too much of a time commitment?

o Would not provide the necessary benefits?

- Are there any other reasons your company has decided to implement some of the provisions of SOX?

\section{PRIOR RESEARCH}

Since the passage of SOX by Congress, most of the research in the area of SOX and publicly-held or privately-held companies has been performed by professional organizations or companies, such as FEI, Robert Half and Associates, and Broadgate Consultants, LLC, E\&Y, etc. One of the early surveys was conducted in July 2003 by Robert Half International Inc. They performed a survey of privately-held companies and found that many of the respondents felt that voluntarily adopting some of the provisions of SOX could better position the companies for establishing strong business credit and obtain major financing. In addition, they are able to enhance relationships and credibility with key stakeholders, since a variety of constituencies increasingly expect firms to uphold a solid reputation for openness and integrity. Furthermore, they found that many private companies are taking a prudent approach and voluntarily adopting key reform standards that are appropriate for their businesses. They believed that SOX would become the benchmark for company behavior and governance and every company would eventually move to the provisions of SOX (Robert Half International, Inc. 2003).

In an Ernst \& Young report, they strongly encourage privately-held companies that are considering entering the public markets or are being considered to be acquired by public companies to establish a time frame to comply with SOX. Their suggestions are extremely appropriate for those specific companies (Ernest \& Young, 2004).

In Illinois, an amendment to the Illinois Public Accounting Act now prohibits CPAs from providing nonauditing services referenced in the Sarbanes-Oxley Act. The prohibition applies if the CPA or firm is contemporaneously providing auditing .services to the client, and the client has annual revenues exceeding $\$ 50$ million, or more than 500 employees. The Act provides an exemption from this prohibition if prior to the commencement of these services, the CPA provides a written notice to the client company explaining that both prohibited non-audit services and audit services are to be provided, and the president or CEO of the company signs an acknowledgement that the company is aware of this and agrees to it. This notice can be incorporated into the engagement letter and signed by the company's president or CEO. To comply with this exemption, the letter must be signed and received by the CPA firm before any of the services are rendered (Practical Accountant, 2004). 


\section{SURVEY APPROACH}

Our research purposes and questions were developed from the sponsored discussed above. Our research project consisted of conducting a survey with financial executives who were members of the Financial Executives International (FEI). The survey was posted several times in a monthly email, referred to as FEI Private Net, sent to FEI members who are financial executives of privately-held companies and the respondents were asked to complete the survey at a survey website. One hundred sixty-one executives responded to the survey. Tables 1 and 2 indicate the respondents' knowledge with SOX and the New York and NASDAQ stock exchange listing requirements. The respondents were familiar with SOX and the New York and NASDAQ stock exchange listing requirements.

\begin{tabular}{|c|c|c|}
\hline \multicolumn{3}{|c|}{ Table 1: How Familiar Are You With The Corporate Governance Reforms } \\
In The Listing Requirements Of The New York Stock Exchange Or The NASDAQ?
\end{tabular}

\begin{tabular}{|c|c|c|}
\hline \multicolumn{2}{|c|}{ Table 2: How Familiar Are You With The Provisions In The Sarbanes-Oxley Act? } \\
\hline & Response Total & \% Response \\
\hline Very familiar & 33 & $20.5 \%$ \\
\hline Somewhat familiar & 116 & $72.0 \%$ \\
\hline Not at all & 12 & $7.5 \%$ \\
\hline Total Respondents & 161 & $100.0 \%$ \\
\hline
\end{tabular}

Also, the respondents were seasoned financial executives. Ninety $\%$ of the respondents were over 40 years of age and had more than 11 years of experience as a financial executive. About $60 \%$ were CPAs and about $56 \%$ had advanced degrees, with $49 \%$ having an MBA.

\begin{tabular}{|c|c|}
\hline \multicolumn{2}{|c|}{ Table 3: What Is Your Age Group? } \\
\hline & \% Response \\
\hline 30-35 years & $3.6 \%$ \\
\hline 36-40 years & $6.5 \%$ \\
\hline $41-45$ years & $14.4 \%$ \\
\hline 46-50 years & $24.5 \%$ \\
\hline 51-55 years & $28.1 \%$ \\
\hline over 55 years & $23.0 \%$ \\
\hline Total Respondents & $100.0 \%$ \\
\hline
\end{tabular}

\begin{tabular}{|c|c|}
\hline \multicolumn{2}{|c|}{ Table 4: How Long Have You Been In A Corporate Financial } \\
\hline \multicolumn{2}{|c|}{ Management Position Such As A Controller CFO Or Financial Executive (In Years)? } \\
\hline \%-5 years & $8.7 \%$ \\
\hline 6-10 years & $10.9 \%$ \\
\hline $11-15$ years & $21.7 \%$ \\
\hline $16-20$ years & $20.3 \%$ \\
\hline $21-25$ years & $23.2 \%$ \\
\hline over 25 years & $15.2 \%$ \\
\hline Total Respondents & $100.0 \%$ \\
\hline
\end{tabular}




\section{SURVEY RESULTS}

In this section of the paper, a discussion of the responses related to the research questions or statements identified above will be presented. The respondents were quite definite that SOX was the benchmark for corporate governance for publicly-held companies. Over $76 \%$ indicated that the Act was the benchmark. This is no surprise since the act relates specifically to publicly-held companies. However, when the same question is asked about whether SOX is the benchmark for privately-held companies, only $22 \%$ either strongly agreed or agreed with that statement and over $60 \%$ responded that they disagreed or strongly disagreed that SOX was the benchmark. These responses are interpreted as a clear indication that financial executives of privately-held companies do not want this Act to dictate corporate governance policies to them.

\begin{tabular}{|c|c|}
\hline \multicolumn{2}{|c|}{ Table 5: I Believe That SOX Is The Benchmark For Publicly-Held Company Governance } \\
\hline Strongly Agree & $\%$ Response \\
\hline Agree & $23.9 \%$ \\
\hline Neutral & $52.1 \%$ \\
\hline Disagree & $10.6 \%$ \\
\hline Strongly Disagree & $12.7 \%$ \\
\hline Total Respondents & $0.7 \%$ \\
\hline
\end{tabular}

\begin{tabular}{|c|c|}
\hline \multicolumn{2}{|c|}{ Table 6: I Believe That SOX Is The Benchmark For Privately-Held Company Governance. } \\
\hline Strongly Agree & $\%$ Response \\
\hline Agree & $2.1 \%$ \\
\hline Neutral & $19.7 \%$ \\
\hline Disagree & $19.0 \%$ \\
\hline Strongly Disagree & $40.8 \%$ \\
\hline Total Respondents & $18.3 \%$ \\
\hline
\end{tabular}

However, many of the financial executives felt that voluntarily implementing some of the provisions of SOX could provide benefits to their companies. As one can see in Table 7, over 50\% of the respondents either agreed or strongly agreed that the voluntary adoption could better position their companies for establishing stronger business credit, major financing options, enhancing credibility with key stakeholders, enhancing relationships with key stakeholders, and taking the company public in the future. Obviously, the most important benefit in implementing some of the provisions of SOX is when the privately-held company is considering going public in the future. They did not feel that implementation could better position themselves for a lower cost of capital from borrowing or a lower cost of insurance. This indicates that the lower cost of capital from borrowing or a lower cost of insurance benefits are likely determined from other factors, such as their overall business risk and financial performance results rather than the mere implementation of SOX. Voluntary adoption of some of the provisions of SOX does appear to lead to a perception that the company does want to improve their opportunities with a variety of constituents, such as creditors, investors, and other stakeholders.

An open-ended question also asked the respondents to identify other benefits that could be derived from the voluntary implementation of SOX. Interestingly, the respondents stated many of the benefits that publicly-held companies derived from the mandatory implementation. They do see a higher level commitment, involvement, and accountability from their senior executive management team towards the overall financial reporting system; they see improvements in their internal controls processes; they see a commitment to attract higher quality financial experts on the Board or Audit Committees; they see a higher level of comfort for Board or Audit Committee members; and, they see an opportunity to develop or continue relationships with specific customers, such as in the area of government contracts. Overall, many of the respondents indicated that they examine each provision of SOX on a cost/benefit and if the benefits are there, they will implement the provision. In many cases, they see SOX as the catalyst for the ability 
to suggest improvements in the overall corporate governance and financial reporting areas. It is our observation that SOX has heightened the awareness of these areas and has now raised it to the attention of management. In the past, these areas were always important, but they never seemed to reach a heightened level for improvement.

\begin{tabular}{|l|c|c|c|c|c|}
\hline \multicolumn{5}{|c|}{$\begin{array}{c}\text { Table 7: I Believe That Privately-Held Companies That Voluntarily } \\
\text { Adopt Some Of The Provisions Of SOX Can Better Position Themselves For: }\end{array}$} \\
\hline & Strongly Agree & Agree & No Opinion & Disagree & Strongly Disagree \\
\hline $\begin{array}{l}\text { Establishing stronger } \\
\text { business credit. }\end{array}$ & $6 \%$ & $44 \%$ & $17 \%$ & $30 \%$ & $4 \%$ \\
\hline Major financing options. & $9 \%$ & $54 \%$ & $15 \%$ & $19 \%$ & $3 \%$ \\
\hline $\begin{array}{l}\text { Enhancing credibility } \\
\text { with key stakeholders. }\end{array}$ & $13 \%$ & $48 \%$ & $11 \%$ & $23 \%$ & $4 \%$ \\
\hline $\begin{array}{l}\text { Enhancing relationships } \\
\text { with key stakeholders. }\end{array}$ & $11 \%$ & $40 \%$ & $18 \%$ & $28 \%$ & $4 \%$ \\
\hline $\begin{array}{l}\text { A lower cost of capital } \\
\text { from borrowing. }\end{array}$ & $4 \%$ & $17 \%$ & $32 \%$ & $43 \%$ & $4 \%$ \\
\hline $\begin{array}{l}\text { A lower cost of } \\
\text { insurance. }\end{array}$ & $4 \%$ & $25 \%$ & $27 \%$ & $38 \%$ & $6 \%$ \\
\hline $\begin{array}{l}\text { Taking the company } \\
\text { public in the future. }\end{array}$ & $48 \%$ & $44 \%$ & $5 \%$ & $2 \%$ & $1 \%$ \\
\hline
\end{tabular}

In terms of changes that are occurring in their company governance policies, the financial executives were asked whether they had already had implemented, were considering implementing, or were not considering implementation for some changes in their policies in the area of an internal audit function, an independent audit committee, a code of professional conduct for the CEO and other financial management, limiting or restricting services provided by your external auditing firm to avoid potential conflicts of interest, a more thorough management discussion and analysis section in the financial statements or annual report, a policy on whistleblower situations, a policy on setting the appointment for the external auditor, a policy on loans to officers, formal certifications of the financial statements, formal certifications of the internal control systems, and guidelines to establish a financial expert on the audit committee or Board of Directors. Table 8 shows the results.

\begin{tabular}{|l|c|c|c|}
\hline \multicolumn{2}{|c|}{ Table 8: Is Your Company Establishing: } \\
\hline & $\begin{array}{c}\text { Already have } \\
\text { implemented }\end{array}$ & $\begin{array}{c}\text { Considering } \\
\text { implementation }\end{array}$ & $\begin{array}{c}\text { Not considering } \\
\text { implementation }\end{array}$ \\
\hline An internal audit function? & $28 \%$ & $13 \%$ & $59 \%$ \\
\hline An independent audit committee? & $42 \%$ & $10 \%$ & $31 \%$ \\
\hline $\begin{array}{l}\text { A code of professional conduct for the CEO and other } \\
\text { financial management? }\end{array}$ & $44 \%$ & $25 \%$ & $43 \%$ \\
\hline $\begin{array}{l}\text { Limiting or restricting services provided by your external } \\
\text { auditing firm to avoid potential conflicts of interest? }\end{array}$ & $40 \%$ & $17 \%$ & $64 \%$ \\
\hline $\begin{array}{l}\text { A more thorough management discussion and analysis } \\
\text { section in the financial statements or annual report? }\end{array}$ & $15 \%$ & $21 \%$ & $51 \%$ \\
\hline A policy on whistleblower situations? & $32 \%$ & $17 \%$ & $50 \%$ \\
\hline $\begin{array}{l}\text { A policy on setting the appointment for the external } \\
\text { auditor? }\end{array}$ & $34 \%$ & $16 \%$ & \\
\hline A policy on loans to officers? & & & \\
\hline Formal certifications of the financial statements? & $42 \%$ & $9 \%$ & $51 \%$ \\
\hline Formail certifications of the internal control systems? & $12 \%$ & $22 \%$ & $48 \%$ \\
\hline $\begin{array}{l}\text { Guidelines to establish a financial expert on the audit } \\
\text { committee or Board of Directors? }\end{array}$ & $26 \%$ & $14 \%$ & $66 \%$ \\
\hline
\end{tabular}


It is a mixed result on whether companies are making significant changes in implementation of company governance policies. In many of these areas, it is a $40 \%$ to $60 \%$ rate of either implementation or considering implementation. But, conversely, this means that either $40 \%$ to $60 \%$ are not considering implementation for many of these issues. Where we see high rates of implementation or consideration of implementation are in areas of an independent audit committee, a code of professional conduct for the CEO and other financial management, limiting or restricting services provided by your external auditing firm to avoid potential conflicts of interest, a policy on whistleblower situations, a policy on setting the appointment for the external auditor, a policy on loans to officers, and formal certifications of the financial statements. However, there is slower progress in the areas of a more thorough management discussion and analysis section in the financial statements or annual report, formal certifications of the internal control systems, and guidelines to establish a financial expert on the audit committee or Board of Directors.

\begin{tabular}{|c|c|}
\hline \multicolumn{2}{|c|}{$\begin{array}{c}\text { Table 9: My Company Feels Pressure } \\
\text { To Implement Some Of The Provisions Of SOX. }\end{array}$} \\
\hline \multicolumn{1}{|c|}{ \% Response } \\
\hline Strongly Agree & $11.4 \%$ \\
\hline Agree & $19.7 \%$ \\
\hline Neutral & $16.7 \%$ \\
\hline Disagree & $31.8 \%$ \\
\hline Strongly Disagree & $20.5 \%$ \\
\hline Total Respondents & $100.0 \%$ \\
\hline
\end{tabular}

\begin{tabular}{|l|c|c|c|c|c|}
\hline \multicolumn{5}{|c|}{ Table 10: If Your Company Has Decided Not To Implement Some } \\
Of The Provisions Of SOX, Your Reasons Not To Do So Are Because SOX Is: \\
\hline & Strongly Agree & Agree & Neutral & Disagree & Strongly Disagree \\
\hline Too costly? & $41 \%$ & $42 \%$ & $13 \%$ & $3 \%$ & $1 \%$ \\
\hline Too much of a time commitment? & $33 \%$ & $45 \%$ & $17 \%$ & $3 \%$ & $2 \%$ \\
\hline $\begin{array}{l}\text { Would not provide the necessary } \\
\text { benefits? }\end{array}$ & $34 \%$ & $46 \%$ & $12 \%$ & $7 \%$ & $1 \%$ \\
\hline
\end{tabular}

Privately-held companies are not feeling significant pressures to implement SOX. Only about $30 \%$ felt some pressure to implement provisions of SOX. The reasons for not implementing any provisions of SOX were related to high costs, too many time demands, and not seeing any positive benefits. However, even though they may not feel pressure to implement some of the provisions of SOX, many of the financial executives felt that application of SOX in some areas made good business sense. They expressed that moving in the spirit of SOX portrayed a positive perception of their organization.

\section{SUMMARY AND CONCLUSIONS}

Our research was designed to for two purposes: (1) if the provisions of SOX have merit on their own or whether it is just a mandate by legislators, and (2) to determine if privately-held companies currently not required to implement SOX have done so. In summary, the respondents, who were experienced financial executives with knowledge of SOX and other regulatory governance policies see SOX as an influential piece of legislation. They see some positive benefits to their organizations with implementation of some of the provisions of the act, such as better financing options, better credit opportunities, and opportunities to take the company public. Many of financial executives indicated their organizations are implementing provisions in areas where it cost effective as well making "good" business sense. For example, it is cost effective to implement a formal code of professional conduct for the executives and it does make good business sense. However they are not asking their CEOs or CFOs to certify the accuracy of financial statements nor to the internal control structure. Many of the financial managers indicated they are not implementing SOX on a full scale basis because of the cost, time, and that the lack of benefits derived from implementation. 
In conclusion, our assessment is that SOX brought about an awareness of many issues that companies should have implemented or considered for the sake of good business. Designing and implementing good internal control structures, having effective codes of conduct for executives, and examining the services and appointments of their CPAs make good business sense. Just as in any business decision, when their organization sees positive benefits over the costs, they are likely to implement and improve the business process.

We believe that CPAs can provide useful suggestions to their privately-held company clients on provisions of Sox that make good business sense. This is an opportunity for CPAs to enhance the services that they provide to their privately-held clients.

\section{FUTURE RESEARCH AREAS}

SOX has created an entire source of future related research regarding publicly-held companies, privately-held companies, and not-for-profit organizations. One of the interesting questions that surfaces is what types of companies and organizations should incorporate the provisions of SOX? As we found in this paper, many privately-held companies are voluntarily implementing less cost oriented provisions of SOX, but are reluctant to implement the costly provisions. But as time and experiences in the implementation of SOX increases, will the marketplace demand more voluntary compliance with the provisions? Will the marketplace reward privately-held companies and not-forprofit organizations that implement more of the costly provisions of SOX? Furthermore, will the judicial system look for a benchmark in company behavior and start to expect privately-held companies and not-for-profit organizations to follow the public-company rules? Also, at the same time, maybe because of the cost factors for companies to comply with SOX, especially in the internal control provision section, will SOX become diluted as we get further away from the scandals that precipitated the Act itself. In short, SOX has many possible research opportunities as the experience with implementing it evolves.

\section{REFERENCES}

1. Block, Stanley B. The Latest Movement to Going Private: An Empirical Study Journal of Applied Finance, Spring/Summer2004, Vol. 14, 1, p 36-44.

2. Why Controllers at Most Private Companies Are Not Voluntarily Complying With Sarbanes-Oxley. Controller's Report, Feb. 2005, 2: 1, p 20-23.

3. Ernst \& Young, LLP. What Private Companies Need To Know About the Sarbanes-Oxley Act. Emerging and Growth Markets, 2004.

4. Most Private Companies Are Adopting Some Sarbanes-Oxley Provisions. Financial Analysis, Planning \& Reporting, Jan. 2005, Vol. 5, 1, p 8.

5. Financial Executives International, FEI Special Survey on Sarbanes-Oxley Section 404 Implementation. Financial Executives International, March 2005.

6. Hoffman, Thomas. Private Companies Feel Effects of Sarbanes-Oxley. Computerworld, August 4, 2003, Vol. $37,3, \mathrm{p} 1$.

7. Impact on Private Company Audits in Illinois. Practical Accountant, Nov. 2004, Vol. 37, 11, p 6.

8. Oshiki, Alan. High Compliance Costs Outweigh Benefits Say Investors, Broadgate Consultants, LLC, March 2005.

9. Rankin, Ken. Slowdown for SOX? Accounting Today, September 6, 2004, Vol. 18, 16, p 1-2.

10. Read, William J.; Rama, Dasaratha V.; Raghunandan, K. Local and Regional Audit Firms and the Market for SEC Audits. Accounting Horizons, Dec 2004, Vol. 18, 4, p 241-254.

11. Robert Half International Inc., The Impact of Sarbanes-Oxley on Private Companies: Are the New Rules Giving Rise to a Universal Standard? July 2003.

12. Sarbanes-Oxley Act (SOA), Public Law No. 107-204, Washington, D.C.: Government Printing Office. 